\title{
Student Success
}

ISSN: 2205-0795

Volume 10, Issue 2, pp. 13-22

August 2019

\section{Using an alternate reality game to facilitate student engagement during orientation*}

\author{
Sarah Glencross, Sandra Elsom, Marguerite Westacott and Colleen Stieler-Hunt \\ University of the Sunshine Coast, Queensland, Australia
}

\section{Abstract}

An alternate reality game was designed to facilitate transition and engagement amongst students commencing a tertiary preparation program at a regional university in Australia. The design of the game was informed by a student engagement framework which proposes four psychosocial constructs which mediate engagement at the intersection between student and institutional influences: self-efficacy, belonging, well-being, and emotion. The 108 participants completed a survey which measured these constructs prior to the commencement of the game. Game players $(n=13)$ were surveyed again immediately after the game. The results of statistical analysis indicated that game players reported a greater sense of well-being and more positive emotions than the group surveyed before the game.

*This article was presented at the STARS Conference in Melbourne, Australia in July 2019 and was selected for publication in this special issue. The authors have kindly given their permission to have this article published and it has undergone a further review by the editors to confirm it aligns with the Journal's submission guidelines and standards.

\section{Please cite this article as:}

Glencross, S., Elsom, S., Westacott, M., \& Stieler-Hunt, C. (2019). Using an alternate reality game to facilitate student engagement during orientation. Student Success, 10(2). 13-22. doi: 10.5204/ssj.v10i2.1298.

This article has been peer reviewed and accepted for publication in Student Success. Please see the Editorial Policies under the 'About' section of the Journal website for further information.

Student Success: A journal exploring the experiences of students in tertiary education

(x) $(9$ articles are free to use with proper attribution. ISSN: 2205-0795 


\section{Introduction}

This paper examines the application of the student engagement framework (Kahu \& Nelson, 2017) to the design of an alternate reality game, The Universal Student, to facilitate transition and engagement for students commencing a tertiary preparation program at a regional university in Australia. Alternate reality games (ARGs), such as The Universal Student, are designed to offer an immersive, interactive experience (Connolly, Stansfield, \& Hainey, 2011). They are a genre of pervasive game in which a narrative unfolds as players solve puzzles and complete real-world tasks, most commonly in collaboration with other players. In an ARG the boundaries of play and who is participating in the play are unclear. This can make well-known, or uninteresting locations seem more exciting (Montola, Stenros, \& Waern, 2009). ARGs can have particular benefits in higher education because of their ability to engage and motivate, to promote collaborative problem solving, and to create organic support networks (Moseley, 2008).

\section{The Universal Student}

The Universal Student is a video-driven alternate reality game designed by a team of academic staff, support staff, and students at a regional university in Australia to facilitate the development of student engagement during orientation. The game is set on the university campus at which the players are enrolled for their studies. It is played in small teams of four or five students and takes approximately one hour to complete. The premise of the game is that an alien has just arrived at the university and is trying to navigate the campus and complete the tasks required of new students. The players are required to collaborate with each other to solve a series of puzzles which are presented to them in the form of video clips and written information. To solve the puzzles, the players are required to visit key locations on campus such as Student Services, the library, a computer lab, Indigenous Services, food outlets, and all-gender toilet facilities. When the players reach the final location of the game they find they have arrived at a party which is attended by staff from the Preparatory and Enabling Unit, Indigenous Services, Academic Support, and Student Wellbeing. The party enables the players to make social connections with peers in other teams whilst also getting to know key members of staff. For further information about the game design, see Elsom \& Westacott (2018, 2019).

The game was designed to support transition by providing students with the opportunity to familiarise themselves with their peers, key members of staff, the campus and the key services available. Further, the game was designed to facilitate engagement by providing opportunities for players to develop the four psychosocial variables which mediate engagement at the intersection between student and institutional influences: selfefficacy, belonging, well-being, and emotion (Kahu \& Nelson, 2017). This study is part of a larger project investigating the design and application of alternate reality games to facilitate engagement (Elsom \& Westacott, 2018, 2019).

\section{Transition theory}

Students' experiences of their transition to higher education have been of interest to researchers for many decades, and research has consistently shown that despite the potential of higher education to provide opportunities for positive transformation, transition to university can be a challenging experience for new students (Kahu, Nelson, \& Picton, 2016; Kift, 2015; O'Donnell et al., 2018). The experience of transition is a complex, multifaceted process which is influenced by environmental characteristics in conjunction with individual differences in reactions to change and ability to cope (Erikson, 1980; Schlossberg, 1981). High school completion does not always equate with readiness for university level study either academically (Harvey, Drew, \& Smith, 2006; 
Henry \& Stahl, 2017) or personally (Kahu, et al., 2017). Likewise, higher education institutions are not always effective in providing new students with the conditions and opportunities necessary for successful transition (Coates, 2005; Kift, 2015; Kift, Nelson, \& Clarke, 2010; Tinto, 1993, 1998, 2006). It has been argued that students face the most difficult period of adjustment during the first year of university (Longwell-Grice \& Longwell-Grice, 2008; Paul \& Brier, 2001; Sevinc \& Gizir, 2014). This difficulty is compounded for students from nontraditional backgrounds (Elsom, Greenaway, \& Marshman, 2017), such as those who are accessing higher education via tertiary preparation or bridging programs (Whannell, Allen, \& Lynch, 2010).

Research into the experience of transition to university has been driven, at least in part, by the positive relationship between effective transition and student engagement which is associated with student retention (Coertjens, Brahm, Trautwein, \& Lindblom-Ylanne, 2016; Kahu et al., 2016; Kift, 2015; Tinto, 1998, 1999) and academic success (Baik, Naylor, \& Arkoudis, 2015; Kahu et al., 2017; Kahu \& Nelson, 2017; Larkin \& Dwyer, 2016; Menzies \& Nelson, 2012). Student engagement is viewed as an essential component of academic success (Kahu, 2013; Kahu et al., 2017; Larkin \& Dwyer, 2016), therefore when institutions design strategies to facilitate student transition it would be prudent for them to align these strategies with factors which have also been demonstrated to directly facilitate student engagement.

\section{Engagement theory}

Student engagement is a complex construct, understood here to be students' involvement in high quality learning and development (Coates, 2009). It is widely viewed as comprising behavioural, psychological, and sociocultural components on the part of the student and the institution (Coertjens et al., 2016; Kahu, 2013, Kahu \& Nelson, 2017; van der Meer, Scott, \&
Pratt, 2018). In common with transition theory, engagement theory recognises the importance of the dynamic interaction between individual factors and institutional factors, and the potential for this interaction to be transformative for the student (Kahu \& Nelson, 2017). Due to this dynamic interaction, it is appropriate to view the construct as situated within an educational interface, the psychosocial space where the educational experience occurs, as exemplified by Kahu and Nelson's (2017) framework of student engagement. This framework locates student engagement, which comprises an individual's emotional, cognitive, and behavioural connection to their university experience, within this interface. Also located within this interface are the four psychosocial constructs which mediate engagement at the intersection between student and institutional influences: self-efficacy, belonging, well-being, and emotion.

\section{Self-efficacy}

An individual's perception of self-efficacy is based upon their judgement of how well they can carry out a course of action to deal with a prospective situation (Bandura, 1982). Within the context of educational institutions, individuals who have stronger beliefs of academic self-efficacy have been shown to have greater levels of motivation with regards to academic tasks (Bandura, Barbaranelli, Caprara, \& Pastorelli, 1996) and clearer academic goals (Zimmerman, Bandura, \& Martinez-Pons, 1992). For example, higher levels of perceived self-efficacy for selfregulated learning have been associated with academic continuance and achievement (Stajkovic, Bandura, Locke, Lee, \& Sergent, 2018). More recently, Tinto (2017) has argued that self-efficacy is an essential component of student persistence which, when viewed through the eyes of students, is a manifestation of motivation and therefore a precursor to academic success. 


\section{Belonging}

Belonging can be defined as a bond, often expressed as a commitment, which connects or integrates the student with a group or community even when challenges occur (Tinto, 1990, 2017). The relationship between belonging and motivation is well established in the literature, for example, in Maslow's (1968) hierarchy of psychological needs, the need for belonging takes precedence over the need for knowledge and understanding. More recently, it has been suggested that belonging is an essential component of student persistence (Tinto, 2017; Wilson et al., 2015). In addition to increased motivation, a sense of belonging also leads to a willingness to connect with others to access support; for example, from peers or university staff in ways that enhance persistence (O'Keeffe, 2013). Developing a sense of belonging is of particular importance for students who are considered to be at risk of non-completion (O'Keeffe, 2013) because a sense of not belonging can undermine a student's motivation to persist with their studies (Tinto, 2017). Students with a greater sense of connectedness to their institution are more likely to successfully complete their studies (Goodenow, 1993; Wilson \& Gore, 2013).

\section{Well-being}

Research on well-being has been derived from the theoretical traditions of hedonia and eudaimonia (Sumi, 2014). In contemporary psychology, hedonia is interpreted as subjective well-being, and operationalised as life satisfaction, the presence of positive affect, and the absence of negative affect (Deci \& Ryan, 2008; Ryan \& Deci, 2000, 2001). Eudaimonia is aligned with humanistic psychology (Silva \& Caetano, 2013), and consists of the subjective experience of personal growth, purpose and meaning in life, and self-realisation (Sumi, 2014). Well-being is considered to be a multidimensional construct which involves optimal functioning (Oades, Robinson, Green, \&
Spence, 2011; Sumi, 2014), and comprises aspects of hedonia and eudaimonia (Deci \& Ryan, 2008; King \& Napa, 1998; McGregor \& Little, 1998). Higher levels of student wellbeing are associated with better academic performance (Wheeler \& Magaletta, 1997). Furthermore, high levels of psychological, emotional and social well-being in students can function as a buffer against performanceinhibiting factors, such as adverse life events, by facilitating adaptive academic behaviour. (Howell, 2009).

\section{Emotions}

Studies of positive emotions have found that they function to build resources: for example, physical resources are built through play (Boulton \& Smith, 1992); intellectual resources are built through processes such as secure attachment which facilitates childhood exploration (Bowlby, 1982); and social resources are built through positive interactions such as altruism (Boulton \& Smith, 1992). Fredrickson and Joiner (2002) found that the experience of positive emotions by university students broadens attention and cognition, which in turn build psychological resilience. More recently, a longitudinal study of Dutch students found that a reciprocal relationship existed between positive emotions, personal resources, and study engagement (Ouweneel, Le Blanc, \& Schaufeli, 2011).

It was hypothesised that after playing The Universal Student, game players would report greater levels of self-efficacy, belonging, and well-being than the group surveyed before the game. It was also hypothesised that there would be a significant association between game playing and emotional state.

\section{Method}

\section{Participants and procedure}

Participants were students commencing a tertiary preparation program at a regional 
university in Australia. Participants were recruited via an announcement during their orientation session. All participants were provided with information about the research rationale and what the game would involve so they could provide informed consent in accordance with the requirements of the university's Human Research Ethics Committee. No incentive was offered for participation. An anonymous online survey was used to gather quantitative data during the orientation session prior to the game $(N=108)$. The students from this group who chose to take part in the game were invited to complete the same survey again immediately after playing $(n=13)$.

\section{Design and Measures}

The design of the study was quasi-experimental and used the Mann-Whitney $U$ test and the Chisquare test of association to compare two independent samples. The parametric data (sense of self-efficacy, belonging, and wellbeing) did not meet the assumption of normal distribution which is required to carry out an independent-samples t-test, therefore these data were analysed using the Mann-Whitney $\mathrm{U}$ test. In order to analyse the categorial data (emotion), a Chi-square test of association was conducted. Statistical analyses were carried out using IBM SPSS Statistics 24.

In the online survey, belonging was measured using the following item, "I have a sense of belonging at [name of university]". Participants provided their response using a 5-point Likert scale from 1 (strongly disagree) to 5 (strongly agree). Self-efficacy was measured using the following item, "I know where to find (have visited/located) the following services or resources". Students were presented with a list of ten key services or locations on campus and were asked to select which ones they had visited or located, for example, the library, Student Services, the amenities, and the lecture theatres. One point was allocated for each location the student had visited or located, possible scores ranged from 0 (low self-efficacy) to 10 (high self-efficacy). Well-being was measured using the following item, "In general, how are you feeling right now?". Participants provided their response using a 3-point Likert scale from 1 (negative) to 3 (positive). Emotion was measured using the following item, "Which word best describes how you are feeling right now?". Participants were asked to select one word from a list of nine words which are commonly used to describe emotions. If a participant selected a word associated with positive emotion, such as "happy" or "excited", they were allocated to the "positive emotion" group. If a participant selected a word associated with negative emotion such as "overwhelmed" or "nervous", they were allocated to the "negative emotion" group.

\section{Results}

A Mann-Whitney $U$ test was conducted comparing the responses prior to the game and immediately after the game (game players group) as shown in Table 1 . The distributions for these two groups were assessed by visual inspection for each result and none were found to be similar.

Statistically significant differences were identified between the groups for belonging ( $p$ $=.022)$ and well-being $(p=.006)$. An examination of the box plots for these groups indicated that the game players group reported a greater sense of well-being and but a lower sense of belonging than the group surveyed before the game.

An examination of the data collected using the online survey revealed that seven of the 13 game players provided partial responses to the question about self-efficacy, whereas they provided full answers to the remainder of the questions. This indicates that there may have been an issue with the design of the question, the way it was presented in the survey interface, or the way that the data were saved during the survey. Under these circumstances, the data are considered to be informatively missing, or, in 


\section{Table 1}

\section{Mann-Whitney $U$ test for responses prior to the game (whole of cohort) and immediately after the game (game players group).}

\begin{tabular}{cccc}
\hline & Belonging & Self-efficacy & Well-being \\
\hline Mann-Whitney U & 950.500 & 587.000 & 413.000 \\
Z & 2.289 & -0.971 & 2.766 \\
Asymp. Sig. (2-tailed) & .022 & .332 & .006 \\
Whole of cohort mean rank & 63.30 & 59.94 & 58.32 \\
Game players mean rank & 41.88 & 69.85 & 82.23 \\
\hline
\end{tabular}

other words, not missing at random (Schlomer, Bauman, \& Card, 2010). A typical technique to address this would be the use of multiple imputation, however it is not possible to apply this technique here because the small sample size and the amount of missing data (over $50 \%$ ) would lead to a significant risk of bias (Schlomer et al., 2010; Sheffer, 2002). It is therefore not appropriate to infer the game's effect on selfefficacy based on the current data set.

A Chi-square test of association was conducted between game playing and emotional state. Three expected cell frequencies were greater than five, one expected cell frequency was five. There was a statistically significant association between game playing and positive emotional state, $\chi^{2}(1)=6.129, p=.013$. The association between game playing and positive emotional state was weak, $\phi=0.275, p=.013$. As one of the cell frequencies was five, a Fisher's exact test was also conducted between game playing and emotional state. There was a statistically significant association between game playing and emotional state, $p=.014$.

\section{Discussion}

The present study contributes to the literature on student transition and engagement by examining the use of an alternate reality game, The Universal Student, to facilitate transition and engagement for students commencing a tertiary preparation program at a regional university in Australia. Specifically, the study identifies the influence of the alternate reality game on the four psychosocial constructs identified in the student engagement framework: self-efficacy, belonging, well-being, and emotions (Kahu \& Nelson, 2017). The results provide partial support for the hypothesis that game players would report higher levels of self-efficacy, belonging, and well-being than the cohort surveyed before the game. Players reported higher levels of wellbeing after the game but lower levels of belonging. The results support the hypothesis that there was a significant association between game playing and emotional state, game players reported a more positive emotional state than non-players.

The finding that the game players reported greater levels of well-being than the cohort surveyed before the game demonstrates that the game has the potential to facilitate feelings of hedonia and eudaimonia. It is generally agreed that there is a considerable overlap between these two states (Ryan \& Deci, 2001) and optimally functioning individuals report high levels of hedonic as well as eudaimonic well-being (Huppert, 2009; Huppert \& So, 2013; Keyes, 2002). Well-being has been conceptualised in various ways depending on the underlying theoretical framework being applied (Sumi, 2014); definitions have included 
emotional, psychological, subjective, and social components (Hone, Jarden, Schofield, \& Duncan, 2014). It is therefore possible that several features of the game contributed to this increased sense of wellbeing, for example, the social component of working as a team and the emotional component of celebrating the successful completion of the game

The significant association with game playing and positive emotional state may, like the finding for well-being, be due to one or more features of the game, such as players' enjoyment of the game, their experience of social connection, and their celebration of successful completion of the game. The positive emotions experienced by game players can be described as evolved psychological adaptions which play a critical role in resource building (Fredrickson, 1998). Whilst the adaptive value of negative emotions is usually immediate, the resources generated through positive emotions are durable and can be deployed at a later time (Fredrickson, 1998). The positive affect reported by game players is an example of the positive emotions which are evolved psychological adaptions that drive dynamic processes, bringing about immediate growth and resilience as well as future health and wellbeing (Fredrickson, 2002; Fredrickson \& Losada, 2005). The positive emotional state experienced by game players also has the potential to positively contribute to the reciprocal relationship between positive emotions, personal resources, and study engagement (Ouweneel et al., 2011).

The finding that game players did not report a greater sense of belonging after they had finished the game was unexpected. In common with other alternate reality games, The Universal Student had been specifically designed to require teamwork and social interaction in order for the tasks to be successfully completed. The finding that the game players did not report a higher level of belonging than the group surveyed before the game could be explained by recent research which found that signs of belonging can become apparent before students commence university and that their sense of connection to the institution can start to develop when they choose which university to attend (Kahu et al., 2016). It is therefore possible that the participants had already developed a sense of belonging to the university prior to playing the game, and there was little scope for it to be increased. Another possible explanation for this finding is that belonging can be experienced at a number of levels, for example, belonging in class, belonging in an academic program, and belonging to the university (Wilson et al., 2015). The online survey only asked students about their sense of belonging to the institution, and as discussed above, this type of belonging may have already been developed prior to orientation week. Further research is required to examine the potential of the game to develop different types of belonging or belonging experienced at different levels.

A limitation of the present research is the small sample size which restricts the generalisability of the data. The lack of data linkages between the cohort surveyed before the game and the game players group is also a limitation. Future research could address this by taking a longitudinal approach where data linkages are used to track individual players and nonplayers throughout their first semester. Another limitation is the missing data in relation to the question about self-efficacy; further research is necessary to further investigate the extent to which The Universal Student can influence students' sense of selfefficacy. Future research could also build on the findings of this study by implementing a research design which enables the identification of specific alternate reality game features, or groups of features, (for example, teamwork or the use of a narrative) which are associated with the development of each of the four psychosocial constructs in Kahu and Nelson's (2017) student engagement framework. Another opportunity for future research would to further develop and validate 
the measures of the four psychosocial constructs and, in particular, to re-develop the measure of belonging in order to incorporate different types and levels of belonging.

Overall, the results of this study indicate that alternate reality games, such as The Universal Student, have the potential to facilitate transition and engagement. Therefore, an opportunity exists for institutions to utilise alternate reality games as part of their orientation program, and, in doing so, bring long-lasting benefits in terms of increased engagement, which in turn has been associated with increased retention and academic success (Baik et al., 2015; Kahu et al., 2017; Kahu \& Nelson, 2017; Larkin \& Dwyer, 2016; Menzies \& Nelson, 2012). In order to do this most effectively, the design of these games should incorporate factors that have been shown to facilitate engagement such as the psychosocial constructs that form part of the student engagement framework (Kahu \& Nelson, 2017).

\section{References}

Baik, C., Naylor, R., \& Arkoudis, S. (2015). The first-year experience in Australian universities: Findings from two decades, 1994-2014. Retrieved from https://melbournecshe.unimelb.edu.au/ data/assets/pdf file/0016/1 513123/FYE-2014-FULL-report-FINAL-web.pdf

Bandura, A. (1982). Self-efficacy mechanism in human agency. American Psychologist, 37(2), 122-147. doi:10.1037/0003-066x.37.2.122.

Bandura, A., Barbaranelli, C., Caprara, G. V., \& Pastorelli, C. (1996). Multifaceted impact of self-efficacy beliefs on academic functioning. Child Development, 67(3), 1206-1222. doi:10.1111/j.14678624.1996.tb01791.x.

Boulton, M. J., \& Smith, P. K. (1992). The social nature of play fighting and play chasing: Mechanisms and strategies underlying cooperation and compromise. In J. H. Barkow, L. Cosmides, \& J. Tooby (Eds.), The adapted mind: Evolutionary psychology and the generation of culture (pp. 429-444). New York, US: Oxford University Press.

Bowlby, J. (1982). Attachment and loss: Retrospect and prospect. American Journal of Orthopsychiatry, 52(4), 664-678. doi:10.1111/j.1939-00251982.tb01456.x.
Coates, H. (2005). The value of student engagement for higher education quality assurance. Quality in Higher Education, 11(1), 25-36. doi:10.1080/13538320500074915

Coates, H. (2009). Engaging Students for Success: Australasian Student Engagement Report. Camberwell, Australia: Australian Council for Educational Research.

Coertjens, L., Brahm, T., Trautwein, C., \& Lindblom-Ylanne, S. (2016). Students' transition into higher education from an international perspective. Higher Education, 73(3), 357-369. doi:10.1007/s10734-016-0092-y.

Connolly, T. M., Stansfield, M., \& Hainey, T. (2011). An alternate reality game for language learning: ARGuing for multilingual motivation. Computers and Education, 57(1),

1389-1415. https://doi.org/10.1016/j.compedu.2011.01.009

Deci, E. L., \& Ryan, R. M. (2008). Hedonia, eudaimonia, and well-being: An introduction. Journal of Happiness Studies, 9(1), 1-11. doi:10.1007/s10902-006-9018-1.

Elsom, S., Greenaway, R., \& Marshman, M. (2017). Experiences of bridging program students at a regional satellite campus. Australian Journal of Adult Learning, 57(2), 242-265. Retrieved from https://www.ajal.net.au/

Elsom, S. \& Westacott, M. (2018, July). Student-Created Serious Games: The Bachelor of Serious Games at the University of the Sunshine Coast. Workshop presented at the Playful Learning Conference, Manchester, UK.

Elsom, S. \& Westacott, M. (2019). Evaluation Report: Games for Education, Learning and Orientation (The GELO Project). Retrieved from http://research.usc.edu.au/vital/access/manager/R epository/usc:28533

Erikson, E. H. (1980). Identity and the life cycle. New York, US: W.W. Norton.

Fredrickson, B. L. (1998). What good are positive emotions? Review of General Psychology, 2(3), 300-319. doi:10.1037/1089-2680.2.3.300.

Fredrickson, B. L., \& Joiner, T. (2002). Positive emotions trigger upward spirals toward emotional well-being. Psychological Science, 13(2), 172-175. https://doi.org/10.1111\%2F1467-9280.00431

Fredrickson, B. L., \& Losada, M. F. (2005). Positive affect and the complex dynamics of human flourishing. American Psychologist, 60(7), 678-686. doi:10.1037/0003-066X.60.7.678.

Goodenow, C. (1993). Classroom belonging among early adolescent students: Relationships to motivation and achievement. The Journal of Early Adolescence, 13(1), 21-43. doi:10.1177/0272431693013001002.

Harvey, L., Drew, S., \& Smith, M. (2006). The First-Year Experience Literature Review: Executive Summary. Retrieved 
https://www.heacademy.ac.uk/knowledgehub/first-year-experience-literature-reviewexecutive-summary

Henry, L., \& Stahl, N. A. (2017). Dismantling the developmental educational pipeline: Potent pedagogies and promising practices that address the college readiness gap. Journal of Adolescent and Adult Literacy, 60(6), 611-616. doi:10.1002/jaal.640.

Hone, L., Jarden, A., Schofield, G., \& Duncan, S. (2014). Measuring flourishing: The impact of operational definitions on the prevalence of high levels of wellbeing. International Journal of Well-Being, 4(1), 62-90. doi:10.5502/ijw.v4i1.4.

Howell, A. J. (2009). Flourishing: Achievement-related correlates of students' well-being. The Journal of Positive Psychology, 4(1), 1-13. doi:10.1080/17439760802043459.

Huppert, F. A. (2009). Psychological well-being: Evidence regarding its causes and consequences. Applied Psychology: Health and Well-Being, 1(2), 137-164. doi:10.1111/j.1758-0854.2009.01008.x.

Huppert, F. A., \& So, T. T. C. (2013). Flourishing across Europe: Application of a new conceptual framework for defining well-being. Social Indicators Research, 110(3), 837-861. doi:10.1007/s11205-011-9966-7.

Kahu, E. R. (2013). Framing student engagement in higher education. Studies in Higher Education, 38(5), 578773. doi:10.1080/03075079.2011.598505.

Kahu, E. R., \& Nelson, K. (2017). Student engagement in the educational interface: understanding the mechanisms of student success. Higher Education Research and Development, 37(1), 58-71. doi:10.1080/07294360.2017.1344197.

Kahu, E. R., Nelson, K. J., \& Picton, C. (2016, July). “I'm excited!" Student expectations prior to starting their first year at university. Paper presented at 2016 STARS Conference Perth, Australia. Retrieved from https://unistars.org/papers/STARS2016/10A.pdf

Kahu, E. R., Nelson, K. J., \& Picton, C. (2017). Student interest as a key driver of engagement for first year students. Student Success, 8(2), 55-66. doi:10.5204/ssj.v8i2.379.

Keyes, C. L. M. (2002). The mental health continuum: From languishing to flourishing in life. Journal of Health and Social Behaviour, 43(2), 207-222. doi:10.2307/3090197.

Kift, S. (2015). A decade of Transition Pedagogy: A quantum leap in conceptualising the first-year experience. HERDSA Review of Higher Education, 2, 51-86. Retrieved from https://www.herdsa.org.au

Kift, S., Nelson, K., \& Clarke, J. (2010). Transition pedagogy: A third generation approach to FYE - A case study of policy and practice for the higher education sector.
International Journal of the First Year in Higher Education, 1(1), 1-20. doi:10.5204/intjfyhe.v1i1.13.

King, L. A., \& Napa, C. K. (1998). What makes a life good? Journal of Personality and Social Psychology, 75(1), 156-165. doi:10.1037/0022-3514.75.1.156.

Larkin, A., \& Dwyer, A. (2016). Supporting non-school leaver students in their first year of university study: Results of a transition focused peer-to-peer intensive mentoring program trial. Journal of Peer Learning, 9(4), 26-40. Retrieved from https://ro.uow.edu.au/ajpl

Longwell-Grice, R., \& Longwell-Grice, H. (2008). Testing Tinto: How do retention theories work for firstgeneration, working-class students? Journal of College Student Retention, 9(4), 407-420. https://doi.org/10.2190\%2FCS.9.4.a

Maslow, A. (1968). Toward a psychology of being. New York: Van Nostrand Reinhold.

McGregor, I., \& Little, B. R. (1998). Personal projects, happiness, and meaning: On doing well and being yourself. The Journal of Personality and Social Psychology, 74(2), 494-512. doi:10.1037//00223514.74.2.494.

Menzies, V.J., \& Nelson, K. J. (2012). Enhancing student success and retention: An institution-wide strategy for peer programs. In R. Mortimer (Ed.), 15 th International First Year in Higher Education Conference (pp. 1-5). Brisbane, Australia: QUT.

Montola, M., Sentros, J., \& Waern, A. (2009). Pervasive Games: Theory and Design. Burlington: Morgan Kaufmann Game Design Books

Moseley, A. (2008). An alternative reality for higher education? Lessons to be learned from online reality games. ALT-C Conference Proceedings, (short paper 260). Leeds, UK: ALT-C.

O’Donnell, M. B., Shirley, L. A., Park, S. S., Nolen, J. P., Gibbons, A. M., \& Rosen, L. A. (2018). The College Adjustment Questionnaire: A measure of students' educational, relational, and psychological adjustment to the college environment. Journal of College Student Development, 59(1), 116-121. doi:10.1353/csd.2018.0009.

O'Keeffe, P. (2013). A sense of belonging: Improving student retention. College Student Journal, 47(4), 605-613. Retrieved from https://www.ingentaconnect.com/

Oades, L. G., Robinson, P., Green, S., \& Spence, G. B. (2011). Towards a positive university. The Journal of Positive Psychology, 6(6), 432-439. doi:10.1080/17439760.2011.634828

Ouweneel, E., Le Blanc, P. M., \& Schaufeli, W. B. (2011). Flourishing students: A longitudinal study on positive emotions, personal resources, and study engagement. The Journal of Positive Psychology, 6(2), 142-153. doi:10.1080/17439760.2011.558847 
Paul, E. L., \& Brier, S. (2001). Friendsickness in the transition to college: Precollege predictors and college adjustment correlates. Journal of Counselling and Development, 79, 77-89. doi:10.1002/j.15566676.2001.tb01946.x.

Ryan, R. M., \& Deci, E. L. (2000). Self-determination theory and the facilitation of intrinsic motivation, social development, and well-being. American Psychologist, 55(1), 68-78. doi:10.1037/0003-066x.55.1.68.

Ryan, R. M., \& Deci, E. L. (2001). On happiness and human potentials: A review of research on hedonic and eudaimonic well-being. Annual Review of Psychology, 52(1), 141-166. doi:10.1146/annurev.psych.52.1.141.

Scheffer, J. (2002). Dealing with missing data. Research Letters in the Information and Mathematical Sciences, 3, 153-160. Retrieved from https://mro.massey.ac.nz/handle/10179/4355

Schlomer, G. L., Bauman, S., \& Card, N. (2010). Best practices for missing data management in counselling psychology. Journal of Counseling Psychology, 57(1), 1-10. doi:10.1037/a00118082

Schlossberg, N. K. (1981). A model for analyzing human adaption to transition. The Counselling Psychologist, 9(2), 2-18. doi:10.1177/001100008100900202.

Sevinc, S., \& Gizir, C. A. (2014). Factors negatively affecting university adjustment from the views of first-year university students: The case of Mersin University. Educational Sciences: Theory and Practice, 14(4), 1301-1308. doi:10.12738/estp.2014.4.2081.

Silva, A. J., \& Caetano, A. (2013). Validation of the flourishing scale and scale of positive and negative experience in Portugal. Social Indicators Research, 110(2), 469-478. doi:10.1007/s11205-011-9938-y.

Stajkovic, A. D., Bandura, A., Locke, E. A., Lee, D., \& Sergent, K. (2018). Test of three conceptual models of influence of the big five personality traits and selfefficacy on academic performance: A meta-analytic path-analysis. Personality and Individual Differences, 120, 238-245. doi:10.1016/j.paid.2017.08.014.

Sumi, K. (2014). Reliability and validity of Japanese versions of the Flourishing Scale and the Scale of Positive and Negative Experience. Social Indicators Research, 118(2), 601-615. doi:10.1007/s11205-013-0432-6.

Tinto, V. (1990). Principles of effective retention. Journal of The Freshman Year Experience, 2(1), 35-48. Retrieved https://sc.edu/about/offices and divisions/national resource center/publications/search/details.php?i $\underline{\mathrm{d}=2225}$

Tinto, V. (1993). Leaving College: Rethinking the Causes and Cures of Student Attrition ( $2^{\text {nd }}$ ed.). Chicago, US: University of Chicago Press.

Tinto, V. (1998). Colleges as communities: Taking research on student persistence seriously. The Review of
Higher Education, 21(2), 167-177. Retrieved from https://muse.jhu.edu

Tinto, V. (1999). Taking retention seriously: Rethinking the first year of college. NACADA Journal, 19(2), 5-9. doi:10.12930/0271-9517-19.2.5.

Tinto, V. (2006). Research and practice of student retention: What next? Journal of College Student Retention, 8(1), 1-19. https://doi.org/10.2190\%2F4YNU-4TMB22DI-AN4W

Tinto, V. (2017). Through the eyes of students. Journal of College Student Retention, 19(3), 254-269. doi: $10.1177 / 1521025115621917$.

van der Meer, J., Scott, S., \& Pratt, K. (2018). First semester academic performance: The importance of early indicators of non-engagement. Student Success, 9(4), 1-12. doi:10.5204/ssj.v9i4.652.

Whannell, R., Alen, B., \& Lynch, K. (2010). Casualties of schooling? 18 to 22-year-old students in a tertiary bridging programs. Australian Journal of Teacher Education, 35(5), 1-17. doi:10.14221/ajte.2010v35n5.1.

Wheeler, R. J., \& Magaletta, P. R. (1997). General well-being and academic performance. Psychological Reports, 80(2), 581-582. doi:10.2466/pr0.1997.80.2.581.

Wilson, S., \& Gore, J. (2013). An attachment model of university connectedness. The Journal of Experimental Education, 81(2), 178-198. doi:10.1080/00220973.2012.699902.

Wilson, S., Jones, D., Bocell, F., Crawford, J., Kim, M. J., Veilleux, N., Plett, M. (2015). Belonging and academic engagement among undergraduate STEM students: A multi-institutional study. Research in Higher Education, 56(7), 750-776. doi:10.1007/s11162015-9367-x.

Zimmerman, B. J., Bandura, A., \& Martinez-Pons, M. (1992). Self-motivation for academic attainment: The role of self-efficacy beliefs and personal goal setting. American Educational Research Journal, 29(3), 663676. doi:10.2307/1163261. 